\title{
Pluripotent Stem Cells in Research and Treatment of Hemoglobinopathies
}

\author{
Natasha Arora and George Q. Daley \\ Department of Biological Chemistry and Molecular Pharmacology, Harvard Medical School, Boston, \\ Massachusetts 02115; Harvard Stem Cell Institute, Cambridge, Massachusetts 02138; Division of Pediatric \\ Hematology/Oncology, Children's Hospital Boston, Boston, Massachusetts 02115 \\ Correspondence: george.daley@childrens.harvard.edu
}

Pluripotent stem cells (PSCs) hold great promise for research and treatment of hemoglobinopathies. In principle, patient-specific induced pluripotent stem cells could be derived from a blood sample, genetically corrected to repair the disease-causing mutation, differentiated into hematopoietic stem cells (HSCs), and returned to the patient to provide a cure through autologous gene and cell therapy. However, there are many challenges at each step of this complex treatment paradigm. Gene repair is currently inefficient in stem cells, but use of zinc finger nucleases and transcription activator-like effector nucleases appear to be a major advance. To date, no successful protocol exists for differentiating PSCs into definitive HSCs. PSCs can be directly differentiated into primitive red blood cells, but not yet in sufficient numbers to enable treating patients, and the cost of clinical scale differentiation is prohibitively expensive with current differentiation methods and efficiencies. Here we review the progress, promise, and remaining hurdles in realizing the potential of PSCs for cell therapy.

Pluripotent stem cells (PSCs), whether embryonic stem cells (ESCs) or induced pluripotent stem cells (iPSCs), have the potential to form any cell type in the body. ESCs are derived from the inner cell mass of the mammalian blastocyst (Evans and Kaufman 1981; Martin 1981; Thomson et al. 1998), whereas iPSCs are somatic cells reprogrammed to a pluripotent state by exogenous expression of transcription factors responsible for conferring pluripotency on ESCs (Takahashi et al. 2007; Yu et al. 2007; Park et al. 2008b). Many diverse types of somatic cells that are readily obtained from patients-like skin fibroblasts, blood, and kerati- nocytes-when transduced with Oct4, Sox2, Klf4, and c-Myc, will revert to a pluripotent state, albeit inefficiently (Aasen et al. 2008; Loh et al. 2009). Although the early reprogramming experiments were performed with retroviruses and lentiviruses, safer transgene-free reprogramming methods have since been developed that use synthetic mRNA or non-integrating episomes to express the reprogramming factors ( $\mathrm{Yu}$ et al. 2009; Warren et al. 2010). In addition, although iPSCs are remarkably similar to ESCs in pluripotent function, many studies have identified subtle but potentially significant molecular differences, showing the need to continue to

Editors: David Weatherall, Alan N. Schechter, and David G. Nathan

Additional Perspectives on Hemoglobin and Its Diseases available at www.perspectivesinmedicine.org

Copyright (C) 2012 Cold Spring Harbor Laboratory Press; all rights reserved; doi: 10.1101/cshperspect.a011841

Cite this article as Cold Spring Harb Perspect Med 2012;2:a011841 
study and improve reprogramming methods to achieve the closest facsimile to the naturally derived ESCs, which remain the gold standard (International Stem Cell Initiative et al. 2007; Kim et al. 2011). With regard to applications for hematologic disease, there appear to be differences in the differentiation potential of human PSC lines to form various tissues of clinical interest, particularly blood (Osafune et al. 2008; Choi et al. 2009). Lanza's group examined the blood differentiation potential of 22 human PSC lines generated at multiple institutions. The 14 human ESC lines tested showed higher hematopoietic colony forming unit (CFU) activity and a 1000-fold increase in erythroid differentiation efficiency, whereas the eight human iPSC lines displayed limited growth potential and decreased CFU activity (Feng et al. 2010).

\section{DISEASE MODELING}

PSCs are a powerful tool for modeling disease. Disease-specific human ESCs have been generated from embryos with genetic mutations causing diseases like thalassemia, Fanconi anemia, and cystic fibrosis (Pickering et al. 2005; Verlinsky et al. 2005; Mateizel et al. 2006; Ben-Yosef et al. 2008). However, affected embryos diagnosed through preimplantation testing are the prerequisite for deriving disease-relevant human ESCs, and because only a subset of predominantly Mendelian genetic disorders are subject to such testing, it is not feasible to obtain human ESCs for any specific disease of interest. On the other hand, to generate disease-specific human iPSCs, only a simple skin biopsy or blood draw from an affected patient is necessary (Park et al. 2008a; Soldner et al. 2009). Fibroblasts can be grown out of the skin biopsy or mononuclear cells collected from the peripheral blood sample and reprogrammed with the four reprogramming factors.

Disease-specific human iPSCs have already been generated for numerous diseases and are being used to model diseases in vitro. Human iPSCs generated from a patient with type 1 diabetes were differentiated into $\beta$-like cells that produced insulin and responded to glucose (Maehr et al. 2009). Parkinson's disease iPSCs were differentiated toward dopaminergic neurons, which were functionally tested in a rat model of Parkinson's disease (Hargus et al. 2010). These studies and numerous others have shown the power of disease-specific human iPSCs in modeling diseases in vitro and represent compelling proof-ofprinciple for the potential of cell therapies.

\section{HEMOGLOBINOPATHIES}

Since the first demonstration of mutant hemoglobin more than a half century ago, hundreds of mutations in the $\alpha$-globin and $\beta$-globin loci have been identified. Many mutations are silent or do not present a clinical phenotype, but a few are common and cause severe phenotypes. Two of the most common hemoglobinopathies caused by these mutations are sickle cell anemia (SCA) and thalassemia.

Sickle cell anemia, caused by an adenine-tothymine point mutation in the sixth codon of the $\beta$-globin gene, changes a polar glutamic acid to a nonpolar valine (Ingram 1956, 1957). This subtle change predisposes hemoglobin to polymerization, which induces rigidity and structural deformations of red blood cells (RBCs), recognized by a characteristic sickling. Sickled RBCs cause vaso-occlusion, which leads to painful crises, organ damage, and premature death (Hofrichter et al. 1974; Crepeau et al. 1978; Dykes et al. 1979; Noguchi and Schechter 1981; Brittenham et al. 1985; Eaton and Hofrichter 1987).

Current treatments for SCA are limited. Hydroxyurea reduces the frequency of painful crises by lowering white blood cell counts, thereby reducing cellular sludging, and increasing production of $\gamma$-globin, a fetal hemoglobin, which reduces RBC sickling (Letvin et al. 1984; Platt et al. 1984). In the setting of disease complications, RBC transfusions can be used to temporarily increase the number of circulating normal RBCs, but frequent RBC transfusions result in sickle antibody sensitization and iron accumulation, which itself causes organ damage (Orlina et al. 1978; Coles et al. 1981; Davies et al. 1986; Reisner et al. 1987; Cox et al. 1988; Rosse et al. 1990; Vichinsky et al. 1990). Bone marrow transplants are a treatment option but are riskier than RBC transfusions, given the potential for graft failure and immunological complications like graft-versus- 
host disease. Marrow transplant can provide a cure but remains an underutilized approach because of the considerable morbidity and mortality associated with such a heroic intervention.

Thalassemias are disorders related to imbalances in the production of the hemoglobin chains that can be caused by several different mutations. In $\alpha$-thalassemia, production of $\alpha$-globin chains is impaired, resulting in free $\beta$-globin polypeptides, which form an unstable hemoglobin molecule (Ingram and Stretton 1959; Ottolenghi et al. 1974; Taylor et al. 1974). In $\beta$-thalassemia, production of $\beta$-globin chains is defective, resulting in free unstable $\alpha$-globin chains that are toxic to erythroid precursors (Fessas 1963; Fessas et al. 1965). As with SCA, treatment options are limited. In severe thalassemia (major), patients require regular transfusion, which comes with the risk of antibody sensitization and the complications of iron overload. Treatments like hydroxyurea, which increase fetal hemoglobin ( $\mathrm{HbF}$ ) levels, reduce the severity of $\beta$-thalassemia because they decrease the number of unpaired $\alpha$-globin chains (Platt et al. 1984; Weatherall 2001; Koren et al. 2008). However, hydroxyurea is not effective in $\beta$-thalassemia patients because they need higher levels of $\mathrm{HbF}$ than SCA patients to ameliorate their symptoms (Alebouyeh et al. 2004; Yavarian et al. 2004). As with SCA, bone marrow transplant is a treatment option and the only chance for a cure; despite the risks of graft failure and graft-versus-host disease, it is frequently used for patients with thalassemia major.

\section{HEMOGLOBINOPATHY DISEASE MODELS - IN VIVO AND IN VITRO}

Two mouse models of $\beta$-thalassemia and one mouse model of $\alpha$-thalassemia have been reported (Skow et al. 1983; Yang et al. 1995; Chang et al. 1996). These models have been used for numerous gene transfer studies to test the efficacy of lentiviruses containing various components of the human $\beta$-globin locus control region (LCR), promoter elements, and $\gamma$-globin or $\beta$-globin gene constructs (May et al. 2000, 2002; Imren et al. 2002; Nishino et al. 2006; Han et al. 2007; Lisowski and Sadelain 2007).
The studies show hemoglobin tetramers containing human $\beta$-globin at levels high enough to ameliorate the disease phenotype.

There are two humanized mouse models of SCA, the "Berkeley" mouse and the "Townes" mouse, which have proven valuable in studying disease mechanisms and testing therapeutic strategies, such as gene therapy (Pawliuk et al. 2001; Xu et al. 2011). The Berkeley mouse is a transgenic strain engineered to express normal human $\alpha$-globin and $\gamma$-globin as well as $\beta^{S}$-globin, the sickle cell mutant (Paszty et al. 1997). The Townes mouse is a knock-in model, in which both the mouse $\alpha$-globin and $\beta$-globin genes were replaced with the human genes. The $\beta$-globin locus contains ${ }^{\mathrm{A}} \gamma$-globin and $\beta^{\mathrm{S}}$-globin (Wu et al. 2006).

In 2002, the first proof-of-principle experiment for combined gene and cell therapy of blood disorders in a murine model was performed using an immunodeficient $\operatorname{Rag}^{-/-}$ mouse strain (Rideout et al. 2002). In this case, Rag2 ${ }^{-/}$ESCs were generated through somatic cell nuclear transfer, a method whereby somatic cells are reprogrammed to pluripotency via nuclear transplantation, creation of a cloned mouse embryo, and extraction of ESCs from the blastocyst stage. One allele of the Rag2 gene was repaired by homologous recombination in the ESCs, which were then differentiated toward hematopoietic precursors and transplanted back into the Rag $2^{-/}$mouse. Upon analysis, the engrafted mice showed mature lymphoid cells. In 2006, a similar experiment was performed with the Townes humanized SCA mouse model (Wu et al. 2006). Autologous ESCs were genetically corrected by homologous recombination, differentiated toward the hematopoietic lineage, and transplanted into the Townes mice. Analysis showed high levels of adult human $\mathrm{HbA}$, reduced RBC sickling, and corrected pathology in the animals. In 2007 with the advent of iPSCs, the same experiment was performed with autologous iPSCs made from the Townes mice (Hanna et al. 2007). This was indeed an impressive demonstration of the potential for harnessing personalized stem cells for the treatment and potential cure of SCA. In a tour de force of modern cell and molecular biology, the Jaenisch 
group derived iPSCs from the murine model of human SCA, restored a normal allele of human $\beta$-globin through homologous recombination, then derived engraftable hematopoietic precursors through directed in vitro differentiation, and treated mice through hematopoietic transplant. Although to date the engraftment of mice with hematopoietic progenitors derived from ESCs/iPSCs remains less robust than from marrow sources, and in mice has required genetic modification of the cells, the therapeutic effect of even partial hematopoietic chimerism is quite dramatic for the hemoglobinopathies, owing to the longer half-life of the repaired cells relative to their diseased counterparts. Consequently, the peripheral blood of engrafted mice shows remarkable restoration of normal erythroid indices, compelling evidence for the potential therapeutic use of iPSCs in hemoglobinopathies.

Two groups have reported the generation of human iPSC models of SCA (Mali et al. 2008; Sebastiano et al. 2011). Zinc finger nucleases (ZFNs) have been used to correct the sickle cell mutation (Sebastiano et al. 2011). However, neither report differentiated the cells and functionally tested them to show sickling or a reduction in sickling after correction.

A handful of human PSC models for thalassemia have also been reported. Human iPSCs derived from $\beta$-thalassemia fibroblasts were used to identify genomic safe harbors for integration of gene therapy vectors (Papapetrou et al. 2010). The study reported human $\beta$-globin levels similar to those of previously reported studies that used mouse models. $\beta$-Thalassemia human ESCs have been generated through nuclear transfer using the nucleus from a fibroblast of a $\beta$-thalassemia patient, which could also be used for cell or gene therapy studies (Fan et al. 2011). Thalassemia human ESCs have also been derived from preimplantation genetic diagnosis embryos (Verlinsky et al. 2005).

\section{CURRENT STATE OF DIRECTED DIFFERENTIATION}

Before using human PSCs for cell therapy, it must first be possible to differentiate human PSCs into the desired cell type for transplanta- tion. In the case of hemoglobinopathies, the desired cells are hematopoietic stem cells (HSCs) or mature RBCs. Second, the issue of autologous cells versus HLA matched cells from a cell bank must be addressed. If a patient's cells are to be used for autologous treatment, then gene correction becomes an extra step.

Deriving large numbers of HSCs from human PSCs is a challenge in the field. Many groups have developed directed differentiation protocols, but most reports analyze $\mathrm{CD} 34^{+}$cells for gene expression, presence of hematopoietic cell surface markers, and CFU potential (Kaufman 2009). High hematopoietic activity in vitro does not, however, correlate with high in vivo engraftment potential when the cells are tested in functional transplant assays (Ledran et al. 2008). One of the biggest challenges in generating HSCs from human PSCs is that HSCs are difficult to maintain in culture, making it difficult to capture, sustain, and expand to clinical scale even if a substantial number of HSCs could be generated in vitro.

Existing directed differentiation protocols use coculture with stromal cell lines or formation of embryoid bodies (EBs), disorganized tissue masses that resemble the early gastrulating mammalian embryo. In all but one report, the percent chimerism of in vitro-derived hematopoietic cells is $<2 \%$, which is significantly less than the chimerism seen from xenotransplants with cord blood cells (Wang et al. 2005; Tian et al. 2006; Ledran et al. 2008; Chicha et al. 2011). Lako's group assessed the effect of primary stromal cells and stromal cell lines from the mouse AGM and fetal liver on hematopoietic differentiation (Ledran et al. 2008). Conditioned medium or extracellular matrix from the stromal lines alone was not sufficient to induce strong hematopoietic differentiation. They reported a down-regulation of pluripotency genes followed by activation of mesodermal and hematopoietic genes. Peak hematopoietic CFU activity and accumulation of CD $34^{+}$cells occurred on Days 18-21 of differentiation and were enhanced by TGF- $\beta$ signaling. Xenotransplants resulted in $2 \%-16 \%$ multilineage donor chimerism, which also engrafted secondary recipients. The highest engraftment was seen from cells cocultured with 
the AGM stromal line. These data, which represent the highest standard to date, are promising yet still significantly short of what would be required before considering scale-up to a clinical stage for human transplantation.

Directly differentiating human PSCs into definitive RBCs has proven equally challenging (Chang et al. 2011). It is possible to generate large numbers of primitive immature RBCs, but generating definitive adult-like RBCs has proven elusive for the field. One group has cultured whole human PSC colonies on immortalized human fetal liver cells until CD $34^{+}$cells arose, then treated the $\mathrm{CD} 34^{+}$cells with hematopoietic differentiation cytokines and cocultured with mouse stromal cells (Olivier et al. 2006; Qiu et al. 2008). A second group cultured whole human PSC colonies on mouse fetal liver stromal cells with hematopoietic differentiation cytokines (Ma et al. 2008). A third group differentiated human PSCs as EBs, which were then directly plated on Matrigel with hematopoietic differentiation cytokines (Chang et al. 2006). A fourth group differentiated human PSCs as EBs, which were then dissociated to single cells and plated in methylcellulose with hematopoietic differentiation cytokines (Lu et al. 2008). Although there are subtle differences among the RBCs generated under each method, they all result in similarly primitive cells. The cells accumulate hemoglobin, appear red in color, and bind oxygen. They mature appropriately as measured by cell surface markers CD71 and CD235a, but remain mostly nucleated and have a primitive hemoglobin expression pattern, expressing $\varepsilon$-globin and $\gamma$-globin with little or no $\beta$-globin. An unanswered question in the field is what mechanism will drive the switch from primitive to definitive RBCs in vitro.

\section{GENE CORRECTION}

The chief advantage of PSCs as targets for combined gene repair and cell therapy is that gene correction is performed in immortalized cells that can be characterized extensively for the fidelity and precision of gene repair and multiple other safety parameters, and the cells can be expanded from a master cell bank to clinical scale before being differentiated into the desired transplantable cell type. A disadvantage is that gene correction is currently inefficient in human PSCs. However, recent work with ZFNs and transcription activator-like effector nucleases (TALENs) has made homologous recombination 200 -fold to 1400 -fold more efficient than standard transfection-based methods (Hockemeyer et al. 2009, 2011; Zou et al. 2009). As a proof-ofprinciple, the point mutation causing $\alpha_{1}$-antitrypsin deficiency has been corrected in human iPSCs with ZFNs (Yusa et al. 2011). Of the colonies that incorporated the correction vector, $54 \%$ were targeted at one allele, and $4 \%$ were targeted at both alleles. The corrected clones differentiated into normal hepatocyte-like cells that did not show the disease phenotype.

Once disease-specific human PSCs are corrected, they must be differentiated into HSCs. However, large numbers of HSCs would need to be generated and maintained long enough to transplant them into the patient, and both directed differentiation and scale-up of cell culture are current challenges for the field. Alternatively, corrected human PSCs could theoretically be differentiated into RBCs for transfusion, but this would provide only a temporary amelioration of disease, in contrast to HSC transplantation, which offers promise of a cure. For patients with antibody sensitization due to multiple prior transfusions, autologous human PSCs might provide a source of compatible RBCs. Because RBCs are enucleate and have a limited life span, such cells could be irradiated before transfusion, eliminating many of the major safety concerns associated with transplantation of stem cells that would otherwise persist in the patient. Indeed, RBC transfusions from autologous human PSCs represent one of the most appealing near-term strategies for cell-based therapies derived from autologous human iPSCs.

\section{PROHIBITIVE COST}

Another major barrier to the widespread application of human PSCs in disease treatment is the high cost of goods for derivation, maintenance, quality control, banking, expansion, and differentiation of cells, made even more cumbersome 
if one envisions personalized therapies. There are $\sim 2 \times 10^{12}$ RBCs per unit for transfusion, but the best of current differentiation methods generates only $10^{10}-10^{11}$ RBCs per six-well plate of human PSCs, meaning that the production of one transfusable unit would require 20 to 200 plates of human PSCs (Lu et al. 2008). For RBC production on a clinical scale, $\sim 2.6 \times$ $10^{9}$ plates of human PSCs would be needed to meet the transfusion needs of only the United States.

The highly specialized maintenance and differentiation media for PSCs is prohibitively expensive, and manual passaging and cell processing are labor intensive. Moreover, for individualized therapies, the cost of the extensive quality analyses that would be required to ensure safety adds considerably to treatment costs. The advantages of immunological identity would have to outweigh the complications of using immune suppression for cells produced as an "offthe-shelf" therapy from a master cell bank, as discussed below. Because human PSCs are adherent cells, opportunities for bioreactor production of large numbers of cells for clinical application are limited.

Currently, cytokines are used to direct the differentiation of human PSCs toward hematopoietic cells, and the costs of cytokines to differentiate human PSCs to RBCs would be prohibitively expensive when considering large-scale production from a cell bank. From an individual's autologous iPSCs, it would be less expensive because of the smaller scale, but the cost would fall on one patient, making patient-specific treatment also prohibitively expensive.

\section{AUTOLOGOUS CELLS VERSUS CELL BANKING}

For cell therapies to become financially feasible, one option is to envision mass production of cells from master cell banks that could be delivered to patients "off-the-shelf," such that economies of scale could be realized for costs of production, maintenance, quality control, and differentiation; and costs could be distributed across a large number of patients. Such an approach would necessarily compromise the chief advantage of personalized, individualized cell therapies-that of immunological identityand would thus require the use of immune suppression, as currently used for organ transplantation. A major question then becomes, what number of PSCs harboring what extent of genetic diversity would be required to constitute a cell bank that might provide a suitable immunological match for most of the human population? Two groups have attempted to model the number of cell lines needed for such a cell bank, based on known immunological heterogeneity of patient populations in the United Kingdom and Japan. The approximations were made using HLA information from registries of kidney transplant recipients, assuming that HLA matching requirements and the use of immune suppression would be similar for solid organ transplants and cell transplants of human PSC derivatives. It is well known that the function and durability of renal allografts is directly proportional to the degree of immunological match, and when considering immunological identity at the human histocompatibility loci HLA-A, HLA-B, and HLA-DR, a single antigen match is considered minimally advantageous. Consequently, in the United Kingdom, a cell bank of 150 randomly chosen human PSC lines would provide a full $6 / 6$ antigen match at HLAA, HLA-B, and HLA-DR for $<20 \%$ of the population, and $37.9 \%$ would have a beneficial match (only one HLA-A or HLA-B mismatch or better), whereas $84.9 \%$ of the population would have a minimally advantageous match at a single HLA-DR locus, or better. However, if the bank is constructed from highly selected human PSCs that harbor homozygous HLA haplotypes (the same A, B, and DR loci on both chromosomes), then only 10 cell lines would provide matches for similar percentages of the population (Taylor et al. 2005). In the Japanese population, a cell bank of 170 human PSC lines would provide a single mismatch or better for $80 \%$ of patients (Nakajima et al. 2007), whereas a cell bank of 30 highly selected homozygous human PSC lines would provide a full match for $82.2 \%$ of the Japanese population, and 50 lines would provide a full match for 73\%-90.7\% (Nakatsuji et al. 2008; Okita and 
Pluripotent Stem Cells in Hemoglobinopathies

Yamanaka 2011). The suspected reason for the difference in beneficial matches is the low ethnic diversity in Japan compared with the United Kingdom, suggesting that the cell bank strategy would be a more reasonable option in less diverse regions and more difficult in regions with high ethnic diversity like the United States.

If a cell bank strategy were to be implemented, depending on the country or region, there would still be a significant percentage of the population for which there would be no beneficial match in the bank. Because of the considerable degree of polymorphism in the HLA loci in human populations, increasing the number of human PSC lines in the cell bank meets a diminishing return and has only a minimal effect on the percentage of the population with a beneficial match. In such cases and for severe disease, the extra effort and expense of personalized cell therapies would have to be considered.

\section{CONCLUDING REMARKS}

We have come a long way from identifying the genetic mutations that cause hemoglobinopathies, but we are still far from a cell therapy treatment or cure. Although the advent of PSCs offers an appealing theoretical platform for treating not only hemoglobinopathies but any of dozens of genetic and malignant bone marrow disorders for which current approaches of bone marrow transplant remain infeasible because of lack of suitable donors or immunological barriers, many hurdles must first be overcome. Advances are needed to improve the efficiency of transgene-free human iPSC derivation, to enhance directed differentiation toward engraftable HSCs or transfusable RBCs, and to reduce the cost of maintaining and differentiating human PSCs in order to make cell therapy treatments feasibly affordable. A hybrid effort, with the majority of the population served by off-the-shelf treatments manufactured from master cell banks, accepting the trade-offs of immune suppression, whereas others are treated with individualized strategies, may ultimately prove the only sustainable mode of delivering innovative cell therapies based on PSCs.

\section{ACKNOWLEDGMENTS}

G.Q.D. is an investigator of the Howard Hughes Medical Institute and the Manton Center for Orphan Disease Research. Research was funded by grants from the US National Institutes of Health (NIH) to G.Q.D. (NHLBI U01HL100001), the Doris Duke Medical Foundation, and the CHB Stem Cell Program.

\section{REFERENCES}

Aasen T, Raya A, Barrero MJ, Garreta E, Consiglio A, Gonzalez F, Vassena R, Bilic J, Pekarik V, Tiscornia G, et al. 2008. Efficient and rapid generation of induced pluripotent stem cells from human keratinocytes. Nat Biotechnol 26: $1276-1284$.

Alebouyeh M, Moussavi F, Haddad-Deylami H, Vossough P. 2004 . Hydroxyurea in the treatment of major $\beta$-thalassemia and importance of genetic screening. Ann Hematol 83: $430-433$.

Ben-Yosef D, Malcov M, Eiges R. 2008. PGD-derived human embryonic stem cell lines as a powerful tool for the study of human genetic disorders. Mol Cell Endocrinol 282: 153-158.

Brittenham GM, Schechter AN, Noguchi CT. 1985. Hemoglobin S polymerization: Primary determinant of the hemolytic and clinical severity of the sickling syndromes. Blood 65: 183-189.

Chang J, Lu RH, Xu SM, Meneses J, Chan K, Pedersen R, Kan YW. 1996. Inactivation of mouse $\alpha$-globin gene by homologous recombination: Mouse model of hemoglobin $\mathrm{H}$ disease. Blood 88: 1846-1851.

Chang KH, Nelson AM, Cao H, Wang L, Nakamoto B, Ware CB, Papayannopoulou T. 2006. Definitive-like erythroid cells derived from human embryonic stem cells coexpress high levels of embryonic and fetal globins with little or no adult globin. Blood 108: 1515-1523.

Chang KH, Bonig H, Papayannopoulou T. 2011. Generation and characterization of erythroid cells from human embryonic stem cells and induced pluripotent stem cells: An overview. Stem Cells Int 2011: 791604.

Chicha L, Feki A, Boni A, Irion O, Hovatta O, Jaconi M. 2011. Human pluripotent stem cells differentiated in fully defined medium generate hematopoietic CD34 ${ }^{-}$and CD $34^{+}$progenitors with distinct characteristics. PLoS ONE 6: e14733.

Choi KD, Yu J, Smuga-Otto K, Salvagiotto G, Rehrauer W, Vodyanik M, Thomson J, Slukvin I. 2009. Hematopoietic and endothelial differentiation of human induced pluripotent stem cells. Stem Cells 27: 559-567.

Coles SM, Klein HG, Holland PV. 1981. Alloimmunization in two multitransfused patient populations. Transfusion 21: $462-466$.

Cox JV, Steane E, Cunningham G, Frenkel EP. 1988. Risk of alloimmunization and delayed hemolytic transfusion reactions in patients with sickle cell disease. Arch Intern Med 148: 2485-2489. 
N. Arora and G.Q. Daley

Crepeau RH, Dykes G, Garrell R, Edelstein SJ. 1978. Diameter of haemoglobin S fibres in sickled cells. Nature 274: 616-617.

Davies SC, McWilliam AC, Hewitt PE, Devenish A, Brozovic M. 1986. Red cell alloimmunization in sickle cell disease. Br J Haematol 63: 241-245.

Dykes GW, Crepeau RH, Edelstein SJ. 1979. Three-dimensional reconstruction of the 14-filament fibers of hemoglobin S. J Mol Biol 130: 451-472.

Eaton WA, Hofrichter J. 1987. Hemoglobin S gelation and sickle cell disease. Blood 70: 1245-1266.

Evans MJ, Kaufman MH. 1981. Establishment in culture of pluripotential cells from mouse embryos. Nature 292: $154-156$.

Fan Y, Jiang Y, Chen X, Ou Z, Yin Y, Huang S, Kou Z, Li Q, Long X, Liu J, et al. 2011. Derivation of cloned human blastocysts by histone deacetylase inhibitor treatment after somatic cell nuclear transfer with $\beta$-thalassemia fibroblasts. Stem Cells Dev 20: 1951-1959.

Feng Q, Lu SJ, Klimanskaya I, Gomes I, Kim D, Chung Y, Honig GR, Kim KS, Lanza R. 2010. Hemangioblastic derivatives from human induced pluripotent stem cells exhibit limited expansion and early senescence. Stem Cells 28: 704-712.

Fessas P. 1963. Inclusions of hemoglobin erythroblasts and erythrocytes of thalassemia. Blood 21: 21-32.

Fessas P, Loukopoulos D, Thorell B. 1965. Absorption spectra of inclusion bodies in $\beta$-thalassemia. Blood 25: 105-109.

Han XD, Lin C, Chang J, Sadelain M, Kan YW. 2007. Fetal gene therapy of $\alpha$-thalassemia in a mouse model. Proc Natl Acad Sci 104: 9007-9011.

Hanna J, Wernig M, Markoulaki S, Sun CW, Meissner A, Cassady JP, Beard C, Brambrink T, Wu LC, Townes TM, et al. 2007. Treatment of sickle cell anemia mouse model with iPS cells generated from autologous skin. Science 318: $1920-1923$.

Hargus G, Cooper O, Deleidi M, Levy A, Lee K, Marlow E, Yow A, Soldner F, Hockemeyer D, Hallett PJ, et al. 2010. Differentiated Parkinson patient-derived induced pluripotent stem cells grow in the adult rodent brain and reduce motor asymmetry in Parkinsonian rats. Proc Natl Acad Sci 107: 15921-15926.

Hockemeyer D, Soldner F, Beard C, Gao Q, Mitalipova M, DeKelver RC, Katibah GE, Amora R, Boydston EA, Zeitler B, et al. 2009. Efficient targeting of expressed and silent genes in human ESCs and iPSCs using zinc-finger nucleases. Nat Biotechnol 27: 851-857.

Hockemeyer D, Wang H, Kiani S, Lai CS, Gao Q, Cassady JP, Cost GJ, Zhang L, Santiago Y, Miller JC, et al. 2011. Genetic engineering of human pluripotent cells using TALE nucleases. Nat Biotechnol 29: 731-734.

Hofrichter J, Ross PD, Eaton WA. 1974. Kinetics and mechanism of deoxyhemoglobin $S$ gelation: A new approach to understanding sickle cell disease. Proc Natl Acad Sci 71: 4864-4868.

Imren S, Payen E, Westerman KA, Pawliuk R, Fabry ME, Eaves CJ, Cavilla B, Wadsworth LD, Beuzard Y, Bouhassira EE, et al. 2002. Permanent and panerythroid correction of murine $\beta$ thalassemia by multiple lentiviral inte- gration in hematopoietic stem cells. Proc Natl Acad Sci 99: 14380-14385.

Ingram VM. 1956. A specific chemical difference between the globins of normal human and sickle-cell anaemia haemoglobin. Nature 178: 792-794.

Ingram VM. 1957. Gene mutations in human haemoglobin: The chemical difference between normal and sickle cell haemoglobin. Nature 180: 326-328.

Ingram VM, Stretton AO. 1959. Genetic basis of the thalassaemia diseases. Nature 184: 1903-1909.

International Stem Cell Initiative, Adewumi O, Aflatoonian B, Ahrlund-Richter L, Amit M, Andrews PW, Beighton G, Bello PA, Benvenisty N, Berry LS, et al. 2007. Characterization of human embryonic stem cell lines by the International Stem Cell Initiative. Nat Biotechnol 25: 803-816.

Kaufman DS. 2009. Toward clinical therapies using hematopoietic cells derived from human pluripotent stem cells. Blood 114: 3513-3523.

Kim K, Zhao R, Doi A, Ng K, Unternaehrer J, Cahan P, Hongguang $\mathrm{H}$, Loh YH, Aryee MJ, Lensch MW, et al. 2011. Donor cell type can influence the epigenome and differentiation potential of human induced pluripotent stem cells. Nat Biotechnol 29: 1117-1119.

Koren A, Levin C, Dgany O, Kransnov T, Elhasid R, Zalman L, Palmor H, Tamary H. 2008. Response to hydroxyurea therapy in beta-thalassemia. Am J Hematol 83(5): 366370 .

Ledran MH, Krassowska A, Armstrong L, Dimmick I, Renstrom J, Lang R, Yung S, Santibanez-Coref M, Dzierzak E, Stojkovic M, et al. 2008. Efficient hematopoietic differentiation of human embryonic stem cells on stromal cells derived from hematopoietic niches. Cell Stem Cell 3: 85-98.

Letvin NL, Linch DC, Beardsley GP, McIntyre KW, Nathan DG. 1984. Augmentation of fetal-hemoglobin production in anemic monkeys by hydroxyurea. $N$ Engl J Med 310: $869-873$.

Lisowski L, Sadelain M. 2007. Locus control region elements HS1 and HS4 enhance the therapeutic efficacy of globin gene transfer in $\beta$-thalassemic mice. Blood 110: $4175-$ 4178.

Loh YH, Agarwal S, Park IH, Urbach A, Huo H, Heffner GC, Kim K, Miller JD, Ng K, Daley GQ. 2009. Generation of induced pluripotent stem cells from human blood. Blood 113: 5476-5479.

Lu SJ, Feng Q, Park JS, Vida L, Lee BS, Strausbauch M, Wettstein PJ, Honig GR, Lanza R. 2008. Biologic properties and enucleation of red blood cells from human embryonic stem cells. Blood 112: 4475-4484.

Ma F, Ebihara Y, Umeda K, Sakai H, Hanada S, Zhang H, Zaike Y, Tsuchida E, Nakahata T, Nakauchi H, et al. 2008. Generation of functional erythrocytes from human embryonic stem cell-derived definitive hematopoiesis. Proc Natl Acad Sci 105: 13087-13092.

Maehr R, Chen S, Snitow M, Ludwig T, Yagasaki L, Goland R, Leibel RL, Melton DA. 2009. Generation of pluripotent stem cells from patients with type 1 diabetes. Proc Natl Acad Sci 106: 15768-15773.

Mali P, Ye Z, Hommond HH, Yu X, Lin J, Chen G, Zou J, Cheng L. 2008. Improved efficiency and pace of 
generating induced pluripotent stem cells from human adult and fetal fibroblasts. Stem Cells 26: 1998-2005.

Martin GR. 1981. Isolation of a pluripotent cell line from early mouse embryos cultured in medium conditioned by teratocarcinoma stem cells. Proc Natl Acad Sci 78(12): 7634-7638.

Mateizel I, De Temmerman N, Ullmann U, Cauffman G, Sermon K, Van de Velde H, De Rycke M, Degreef E, Devroey P, Liebaers I, et al. 2006. Derivation of human embryonic stem cell lines from embryos obtained after IVF and after PGD for monogenic disorders. Hum Reprod 21: 503-511.

May C, Rivella S, Callegari J, Heller G, Gaensler KM, Luzzatto L, Sadelain M. 2000. Therapeutic haemoglobin synthesis in $\beta$-thalassaemic mice expressing lentivirus-encoded human $\beta$-globin. Nature 406: 82-86.

May C, Rivella S, Chadburn A, Sadelain M. 2002. Successful treatment of murine $\beta$-thalassemia intermedia by transfer of the human $\beta$-globin gene. Blood 99: 1902-1908.

Nakajima F, Tokunaga K, Nakatsuji N. 2007. Human leukocyte antigen matching estimations in a hypothetical bank of human embryonic stem cell lines in the Japanese population for use in cell transplantation therapy. Stem Cells 25: 983-985.

Nakatsuji N, Nakajima F, Tokunaga K. 2008. HLA-haplotype banking and iPS cells. Nat Biotechnol 26: 739-740.

Nishino T, Cao H, Stamatoyannopoulos G, Emery DW. 2006. Effects of human $\gamma$-globin in murine $\beta$-thalassaemia. Br J Haematol 134: 100-108.

Noguchi CT, Schechter AN. 1981. The intracellular polymerization of sickle hemoglobin and its relevance to sickle cell disease. Blood 58: 1057-1068.

Okita K, Yamanaka S. 2011. Induced pluripotent stem cells: Opportunities and challenges. Philos Trans R Soc Lond B Biol Sci 366: 2198-2207.

Olivier EN, Qiu C, Velho M, Hirsch RE, Bouhassira EE. 2006. Large-scale production of embryonic red blood cells from human embryonic stem cells. Exp Hematol 34: 1635-1642.

Orlina AR, Unger PJ, Koshy M. 1978. Post-transfusion alloimmunization in patients with sickle cell disease. Am J Hematol 5: 101-106.

Osafune K, Caron L, Borowiak M, Martinez RJ, Fitz-Gerald CS, Sato Y, Cowan CA, Chien KR, Melton DA. 2008. Marked differences in differentiation propensity among human embryonic stem cell lines. Nat Biotechnol 26: 313-315.

Ottolenghi S, Lanyon WG, Paul J, Williamson R, Weatherall DJ, Clegg JB, Pritchard J, Pootrakul S, Boon WH. 1974. The severe form of $\alpha$ thalassaemia is caused by a haemoglobin gene deletion. Nature 251: 389-392.

Papapetrou EP, Lee G, Malani N, Setty M, Riviere I, Tirunagari LM, Kadota K, Roth SL, Giardina P, Viale A, et al. 2010. Genomic safe harbors permit high $\beta$-globin transgene expression in thalassemia induced pluripotent stem cells. Nat Biotechnol 29: 73-78.

Park IH, Arora N, Huo H, Maherali N, Ahfeldt T, Shimamura A, Lensch MW, Cowan C, Hochedlinger K, Daley GQ. 2008a. Disease-specific induced pluripotent stem cells. Cell 134: $877-886$.
Park IH, Lerou PH, Zhao R, Huo H, Daley GQ. 2008b. Generation of human-induced pluripotent stem cells. Nat Protoc 3: 1180-1186.

Paszty C, Brion CM, Manci E, Witkowska HE, Stevens ME, Mohandas N, Rubin EM. 1997. Transgenic knockout mice with exclusively human sickle hemoglobin and sickle cell disease. Science 278: 876-878.

Pawliuk R, Westerman KA, Fabry ME, Payen E, Tighe R, Bouhassira EE, Acharya SA, Ellis J, London IM, Eaves CJ, et al. 2001. Correction of sickle cell disease in transgenic mouse models by gene therapy. Science 294: 2368-2371.

Pickering SJ, Minger SL, Patel M, Taylor H, Black C, Burns CJ, Ekonomou A, Braude PR. 2005. Generation of a human embryonic stem cell line encoding the cystic fibrosis mutation $\Delta \mathrm{F} 508$, using preimplantation genetic diagnosis. Reprod Biomed Online 10: 390-397.

Platt OS, Orkin SH, Dover G, Beardsley GP, Miller B, Nathan DG. 1984. Hydroxyurea enhances fetal hemoglobin production in sickle cell anemia. J Clin Invest 74: 652-656.

Qiu C, Olivier EN, Velho M, Bouhassira EE. 2008. Globin switches in yolk sac-like primitive and fetal-like definitive red blood cells produced from human embryonic stem cells. Blood 111: 2400-2408.

Reisner EG, Kostyu DD, Phillips G, Walker C, Dawson DV. 1987. Alloantibody responses in multiply transfused sickle cell patients. Tissue Antigens 30: 161-166.

Rideout WM III, Hochedlinger K, Kyba M, Daley GQ, Jaenisch R. 2002. Correction of a genetic defect by nuclear transplantation and combined cell and gene therapy. Cell 109: $17-27$.

Rosse WF, Gallagher D, Kinney TR, Castro O, Dosik H, Moohr J, Wang W, Levy PS. 1990. Transfusion and alloimmunization in sickle cell disease. The Cooperative Study of Sickle Cell Disease. Blood 76: 1431-1437.

Sebastiano V, Maeder ML, Angstman JF, Haddad B, Khayter C, Yeo DT, Goodwin MJ, Hawkins JS, Ramirez CL, Batista LF, et al. 2011. In situ genetic correction of the sickle cell anemia mutation in human induced pluripotent stem cells using engineered zinc finger nucleases. Stem Cells 29: $1717-1726$.

Skow LC, Burkhart BA, Johnson FM, Popp RA, Popp DM, Goldberg SZ, Anderson WF, Barnett LB, Lewis SE. 1983. A mouse model for $\beta$-thalassemia. Cell 34: 1043-1052.

Soldner F, Hockemeyer D, Beard C, Gao Q, Bell GW, Cook EG, Hargus G, Blak A, Cooper O, Mitalipova M, et al. 2009. Parkinson's disease patient-derived induced pluripotent stem cells free of viral reprogramming factors. Cell 136: 964-977.

Takahashi K, Tanabe K, Ohnuki M, Narita M, Ichisaka T, Tomoda K, Yamanaka S. 2007. Induction of pluripotent stem cells from adult human fibroblasts by defined factors. Cell 131: 861-872.

Taylor JM, Dozy A, Kan YW, Varmus HE, Lie-Injo LE, Ganesan J, Todd D. 1974. Genetic lesion in homozygous a thalassaemia (hydrops fetalis). Nature 251: 392-393.

Taylor CJ, Bolton EM, Pocock S, Sharples LD, Pedersen RA, Bradley JA. 2005. Banking on human embryonic stem cells: Estimating the number of donor cell lines needed for HLA matching. Lancet 366: 2019-2025. 
N. Arora and G.Q. Daley

Thomson JA, Itskovitz-Eldor J, Shapiro SS, Waknitz MA, Swiergiel JJ, Marshall VS, Jones JM. 1998. Embryonic stem cell lines derived from human blastocysts. Science 282: $1145-1147$.

Tian X, Woll PS, Morris JK, Linehan JL, Kaufman DS. 2006. Hematopoietic engraftment of human embryonic stem cell-derived cells is regulated by recipient innate immunity. Stem Cells 24: 1370-1380.

Verlinsky Y, Strelchenko N, Kukharenko V, Rechitsky S, Verlinsky O, Galat V, Kuliev A. 2005. Human embryonic stem cell lines with genetic disorders. Reprod Biomed Online 10: 105-110.

Vichinsky EP, Earles A, Johnson RA, Hoag MS, Williams A, Lubin B. 1990. Alloimmunization in sickle cell anemia and transfusion of racially unmatched blood. $N$ Engl $J$ Med 322: 1617-1621.

Wang L, Menendez P, Shojaei F, Li L, Mazurier F, Dick JE, Cerdan C, Levac K, Bhatia M. 2005. Generation of hematopoietic repopulating cells from human embryonic stem cells independent of ectopic HOXB4 expression. J Exp Med 201: 1603-1614.

Warren L, Manos PD, Ahfeldt T, Loh YH, Li H, Lau F, Ebina W, Mandal PK, Smith ZD, Meissner A, et al. 2010. Highly efficient reprogramming to pluripotency and directed differentiation of human cells with synthetic modified mRNA. Cell Stem Cell 7: 618-630.

Weatherall DJ. 2001. Phenotype-genotype relationships in monogenic disease: Lessons from the thalassaemias. Nat Rev Genet 2: 245-255.

Wu LC, Sun CW, Ryan TM, Pawlik KM, Ren J, Townes TM. 2006. Correction of sickle cell disease by homologous recombination in embryonic stem cells. Blood 108: $1183-1188$.

Xu J, Peng C, Sankaran VG, Shao Z, Esrick EB, Chong BG, Ippolito GC, Fujiwara Y, Ebert BL, Tucker PW, et al. 2011. Correction of sickle cell disease in adult mice by interference with fetal hemoglobin silencing. Science 334: $993-$ 996.

Yang B, Kirby S, Lewis J, Detloff PJ, Maeda N, Smithies O. 1995. A mouse model for $\beta^{0}$-thalassemia. Proc Natl Acad Sci 92: 11608-11612.

Yavarian M, Karimi M, Bakker E, Harteveld CL, Giordano PC. 2004. Response to hydroxyurea treatment in Iranian transfusion-dependent $\beta$-thalassemia patients. Haematologica 89: 1172-1178.

Yu J, Vodyanik MA, Smuga-Otto K, Antosiewicz-Bourget J, Frane JL, Tian S, Nie J, Jonsdottir GA, Ruotti V, Stewart R et al. 2007. Induced pluripotent stem cell lines derived from human somatic cells. Science 318: 1917-1920.

Yu J, Hu K, Smuga-Otto K, Tian S, Stewart R, Slukvin II, Thomson JA. 2009. Human induced pluripotent stem cells free of vector and transgene sequences. Science 324: 797-801.

Yusa K, Rashid ST, Strick-Marchand H, Varela I, Liu PQ, Paschon DE, Miranda E, Ordonez A, Hannan NR, Rouhani FJ, et al. 2011. Targeted gene correction of $\alpha 1$-antitrypsin deficiency in induced pluripotent stem cells. $\mathrm{Na}$ ture 478: 391-394.

Zou J, Maeder ML, Mali P, Pruett-Miller SM, ThibodeauBeganny S, Chou BK, Chen G, Ye Z, Park IH, Daley GQ, et al. 2009. Gene targeting of a disease-related gene in human induced pluripotent stem and embryonic stem cells. Cell Stem Cell 5: 97-110. 


\title{
$\&_{\mathrm{CSH}}^{\infty} \&$ Cold Spring Harbor

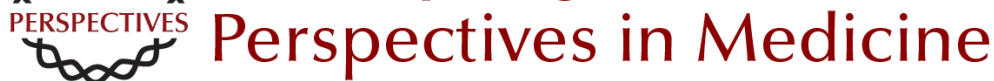

\section{Pluripotent Stem Cells in Research and Treatment of Hemoglobinopathies}

\author{
Natasha Arora and George Q. Daley \\ Cold Spring Harb Perspect Med 2012; doi: 10.1101/cshperspect.a011841
}

\section{Subject Collection Hemoglobin and Its Diseases}

The Natural History of Sickle Cell Disease

Graham R. Serjeant

\section{Current Management of Sickle Cell Anemia} Patrick T. McGann, Alecia C. Nero and Russell E. Ware

Cell-Free Hemoglobin and Its Scavenger Proteins: New Disease Models Leading the Way to Targeted Therapies

Dominik J. Schaer and Paul W. Buehler

Clinical Manifestations of $\alpha$-Thalassemia Elliott P. Vichinsky

Erythroid Heme Biosynthesis and Its Disorders Harry A. Dailey and Peter N. Meissner

Hemoglobin Variants: Biochemical Properties and Clinical Correlates Christopher S. Thom, Claire F. Dickson, David A. Gell, et al.

The Prevention of Thalassemia Antonio Cao and Yuet Wai Kan

The Switch from Fetal to Adult Hemoglobin Vijay G. Sankaran and Stuart H. Orkin
Transcriptional Mechanisms Underlying

Hemoglobin Synthesis

Koichi R. Katsumura, Andrew W. DeVilbiss, Nathaniel J. Pope, et al.

Iron Deficiency Anemia: A Common and Curable

Disease

Jeffery L. Miller

Management of the Thalassemias

Nancy F. Olivieri and Gary M. Brittenham

The Molecular Basis of $\beta$-Thalassemia Swee Lay Thein

Erythropoiesis: Development and Differentiation Elaine Dzierzak and Sjaak Philipsen

Erythropoietin

H. Franklin Bunn

Classification of the Disorders of Hemoglobin Bernard G. Forget and H. Franklin Bunn

The Molecular Basis of $\alpha$-Thalassemia Douglas R. Higgs

For additional articles in this collection, see http://perspectivesinmedicine.cshlp.org/cgi/collection/ 